\title{
Let's Leverage On Twitter Framework in Propagating Malay Proverbs (Peribahasa) to the New Generation. Our Proverbs: Use It! (Peribahasa Kita: Gunakanlah!)
}

\author{
Nurhazman Abdul Aziz \\ Nanyang Technological University, Library \\ 50 Nanyang Avenue, Singapore 639798 \\ nurhazman@ntu.edu.sg \\ Juffri Supa'at \\ National Library Board \\ 100 Victoria Street \#14-01, Singapore 188064 \\ juffri_supaat@nlb.gov.sg
}

\begin{abstract}
Proverbs or better known as Peribahasa, in the Malay Language has been an integral component in learning and understanding the Malay culture. It is also part of the Malay Language curriculum to be imparted to our students during their primary, secondary education and even for their postsecondary education in junior colleges in preparation for the Primary School Leaving Examination (PSLE), Singapore-Cambridge General Certificate of Education Normal, Ordinary, Advanced Level examinations in Singapore. With the advent of today's information \& communication technology, raises the concept of New Media literacy among our youths. One of the commonly New Media tools that the majority youths in the ASEAN region, especially Singapore, have adopting is Twitter (http://twitter.com). Twitter is a micro-blogging service that allows users to tweet about any topics within the 140-character limit and follow others to receive their tweets. In this paper, the illustration of the twitter technology proposed by the technology librarian with national reference librarian (specialised in language development - Malay) are to explore, deploy and leverage on the capability to create a knowledge awareness and immersive model in propagating Malay Proverbs (Peribahasa) to the new generation within the Twitter sphere. This initiative is introduced to strategically spread them through the digital engagement among the new generation and at the same times expose the surface knowledge of peribahasa among the online community. Most language learners do not need even more passive input in form of texts, lectures or videos. This input is readily available in numerous forms on the Internet. Basically, they need is the opportunity to actively produce peribahasa language and the chance to use them as tool of communication. This addresses for instructional methods and tools promoting 'active' learning allowing to express themselves and interact in the target language and cultural. The paper will explores and discusses (i) on the technology - twitter, (ii) digital demo graph and cultural, (iii) the use of language (peribahasa), (vi) the framework and lastly (v) the benefit and return of investment.
\end{abstract}

\section{KEYWORDS}

Library Science, Language, Knowledge Awareness, Literacy, Knowledge Immersive, New Media, Social Media, Digital Engagement, Campaign 


\section{INTRODUCTION}

Twitter was introduced in 2006 (Farhi, 2009), when the main objective was to be answer and question type. Or even random thoughts, rambling or just saying with limited 140 characters messages. On top, to allow two ways communication (or interactivity), the development allows the users opted to "follow" another users and this are made mobile ready. Aside, at that period, access the web via mobile gadget is one of the raising adoptions in the community. Especially, with the introduce of iPhone (Honan, 2007) that included its Safari web browser. The phone can use its Internet capabilities to view standard Web pages, rather than WAP versions of pages. This marks the advent of technology for the community to explore the information explosion in certain behaviour. In a progressive communication, via Twitter, it was becoming a way to form connections in real time with thousands of people who shared the interests (Sarno, 2009) or a way to get to know strangers through the details of their lives (Thompson, 2008). In addition, researchers began studying Twitter and found that people were using it to give and receive advice, gather and share information, and meet people (Johnson \& Yang, 2009). People tweeted about a range of topics, including events of daily life, and linked to news stories (Java, Xiaodan, Finin, \& Tseng, 2007).

Today, Twitter evolves from an online application where users answered a simple question to a " "new economy of info-sharing and connectivity" between people (Sarno, 2009). Many research papers has found that this sharing of everyday experiences and chitchat online help people establish common ground and can bring people together through social media (Donath \& Boyd, 2004; Rheingold, 2000). And, this is proven in a number of recent incidents such as The Arab Spring incidents (A. Dunn, 2011; Grossman, 2009; Saletan, 2011; Tumasjan, Sprenger, Sandner, \& Welpe, 2010). From here, twitter has proven that it has morph into one form of main communication channel in most of our daily life; especially every mobile device has a twitter application installed.

Till today, Twitter has surpassed 500 million registered users worldwide (Dugan, 2012). In Singapore, there is an increase of Singaporeans' related twitter account since 2010 (Yung Hui, 2010) that is more than $900 \mathrm{~K}$ twitter, as illustrated in table below.

In 2011, Singaporeans faced the impact social media at two national levels, the 2011 election and the SMRT cases in December as the citizen begins to communicate with each other within the instant 14 characters limitation (Choy, Cheong, Laik, \& Shung, 2011; Ortmann, 2011; Yung Hui, 2010). In this phenomenon of communication trends, the citizen managed to send a message to the governing body in an indirect rhetoric approach with on the concerns express, creating a viral ripple

\begin{tabular}{|llll}
\hline \multicolumn{3}{|c|}{ Asian Countries, by × of Twitter Users and Total Users } \\
\hline No. & Country & $\begin{array}{l}\text { X of Twitter Users } \\
\text { (Sysomos report) }\end{array}$ & Estimated Total Twitter Users \\
\hline 1 & Indonesia & 2.34 & $2,475,245$ \\
\hline 2 & Japan & 1.47 & $1,554,962$ \\
\hline 3 & India & 0.97 & $1,026,063$ \\
\hline 4 & Singapore & 0.88 & 930,861 \\
\hline 5 & Philippines & 0.85 & 899,128 \\
\hline 6 & Malaysia & 0.47 & 497,165 \\
\hline 7 & Thailand & 0.30 & 317,339 \\
\hline 8 & China & 0.23 & 243,293 \\
\hline 8 & South Korea & 0.23 & 243,293 \\
\hline
\end{tabular}
impacts. Till today, for example on the case for SMRT (Musfirah, 2012; Oiong, 2012), the Committee of Inquiry (COI) is still an on-going process at the national level.

Initially, Twitter has started off as a fun social media for up with friends and sharing updates about daily life, but it have evolved deeper and grown. In the education area, Duff (2012) shares 100 ways to use Twitter in education, by degree of difficulty. It is up to the academic or just interested in building his/her Twitter profile, keep reading to learn some tips and tricks that can help them to take 
the first steps towards using Twitter for coursework, research, building a professional network, and beyond. Creativity in creating the knowledge model is illustrated for this approach to facilitate an interactive learning behaviour through knowledge awareness, knowledge management, knowledge development and leading to knowledge immersive. In addition, this idea is expressed and shared in the research to create an information concierge for the new librarianship professional (Foo, Judy, \& A, 2008). Going virtual for enhanced library experience also leads to the proposal for the profession to evolves a number of roles that libraries can play in such a future: as info concierges; as a network of inter-connected info-concierges; and as a network of true collaborations in the mentioned paper. Thus, leveraging on Twitter's infrastructure, via the exploration in the anatomy of twitter, there is a feasible idea can be studies and initiate to introduce knowledge awareness and immersive of propagating Malay Proverbs (Peribahasa) to the new generation within the Twitter sphere.

\section{ANATOMY OF TWITER INFORMATION STRUCTURE}

Before, the idea could be introduced forward, a tweet is not actually just 140 characters of text that is send into the cloud. Most developer building tools on top of the platform are aware that tweets contain far more information than a brief passing thought that everyone felt the urge to share with the community via micro blogging network

Think again. To developers building tools on top of the Twitter platform, they know tweets contain far more information than just whatever brief, passing thought you felt the urge to share with your friends via the micro blogging network. A tweet is filled with metadata - information about when it was sent, by who, using what Twitter application and so on (Perez, 2010). Raffi Krikorian (Krikorian, 2010), a developer on Twitter's API/Platform team shares map using "JSON as opposed to XML" since the company is "considering not supporting XML on v2 of the API." Even though, this may mean nothing to everyday Twitter users, but it's important information for developers to take note of the map below. This map is all the more interesting when the proposal leads to the consideration in the limitation in a tweet's data map's richness will soon evolves.

In addition, with the introduction of Twitter Annotation in 2010, this has led to higher innovation in using and leveraging the tool (Ingram, 2010; Kirkpatrick, 2010; Krikorian, 2010; Siegler, 2010). Basically, it is a system for any metadata to be connected to any Twitter message when it is published.

Inside every Tweet, there is now a space where users could put or find anything, including links out to further instructions or larger bodies of information. For example, (1) a twitter can be link to a media file, like

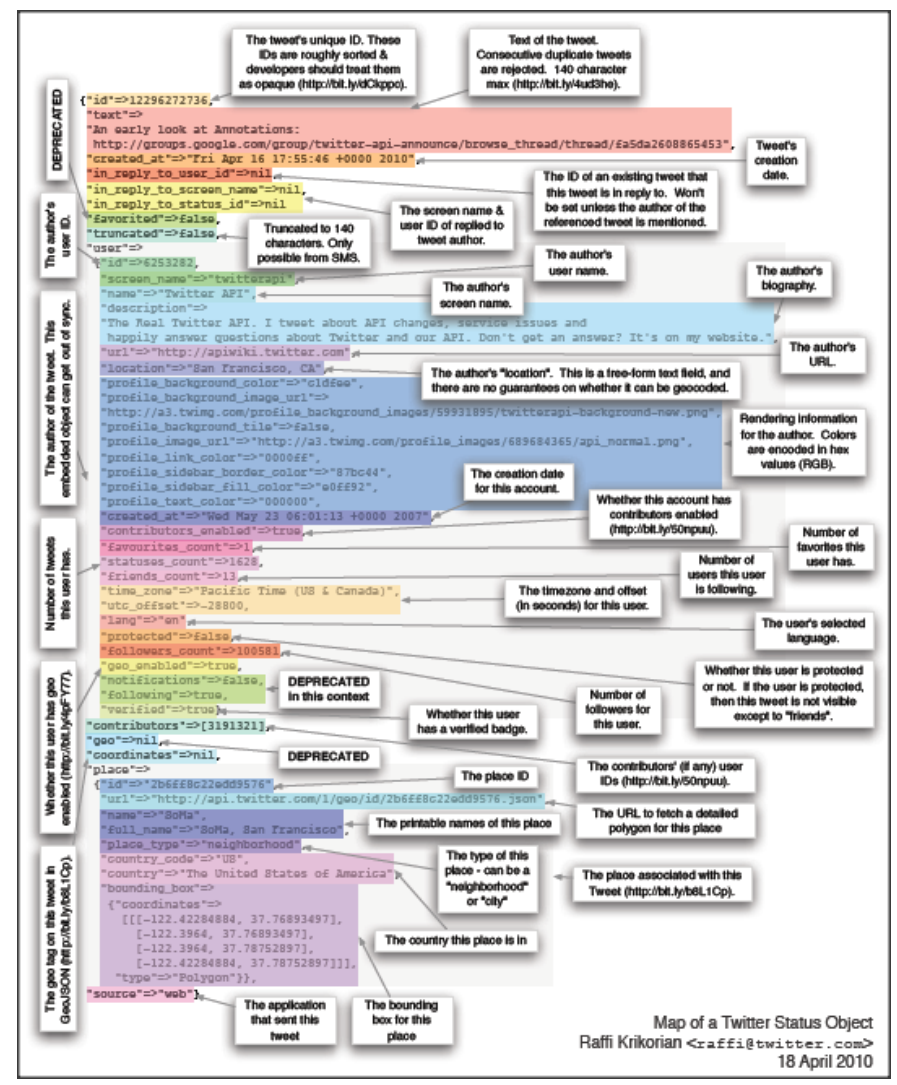
podcast enclosures, photos linked to, etc. And, (2) the context in the Tweet such as, (i) where was the author when it was published, maybe (ii) what the weather was like there at the time. Furthermore, (3) a twitter publishing interface could offer a special option to write reviews of movies, books, or links that they are sharing. The ISBN of the book, a link to a preview of the movie and the number of stars in ratings could be included in the Tweet Annotations. Or, (4) in any 
way user can classify, describe, append or otherwise enrich a Tweet with words or numbers can be included in Annotations.

And, in a layman's term for a user (librarian) to harness and leverage this social media platform, there are basic eight points in strategic guide for them to know, especially when creating a twitter's presence, as illustrated:-

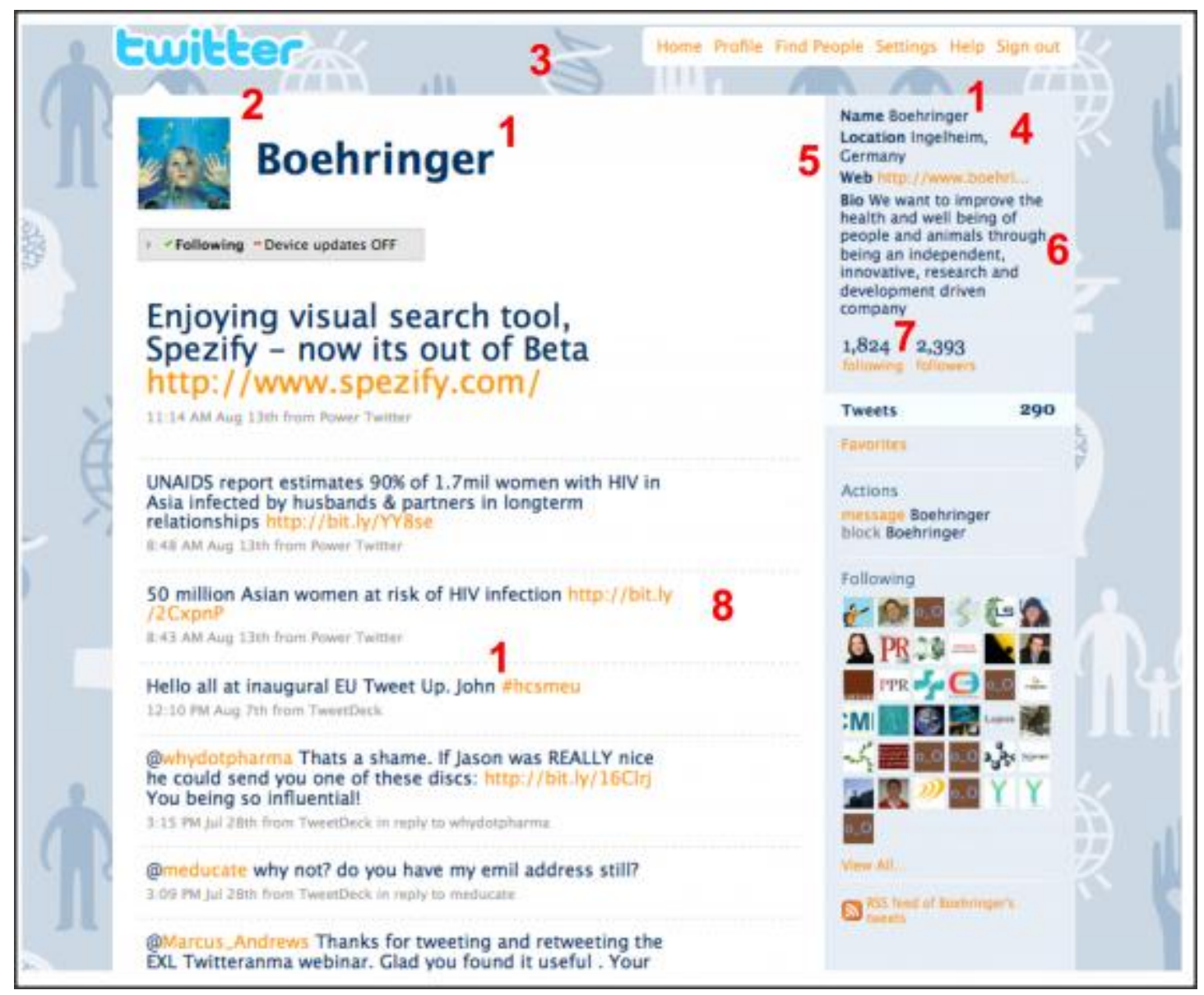

\section{What's in a name}

This is referring to the username (15 characters maximum, next to the avatar) and name (20 characters maximum, appears at the top of the right hand column). Librarian can select to use a corporate identity or a personal one. Officially, at the Twitter settings page, it is explicit about why entering user's own monicker in the name field is a good idea: 'Enter your real name, so people you know can recognize you'. This is because it is a great way of placing the commitment to transparency front-and-centre. It allows the followers know who the librarians are in order. Thus, there can be no misunderstanding as to whom the voice behind the tweets is published belongs.

\section{Get a picture (The Avatar)}

The real question when using avatar (or own photos) is all about personal versus business branding. User has the choice to understand the point of photos is to make the connection that there is a person behind the business (outreach). The most important objective is user is able to establish and develop relationship using the correct avatar. And, there is a human's touch.

\section{Foreground the background}

Twitter allows users to align background image and design colours with the strategic goals. 
The design can be consist with a clever collage of symbols that shares positive things about the service, product or outreach. This will lead to an opportunity that will contrast and resemble with an opportunity perceived and executed.

\section{Know where you've come from, know where you're going}

There is a location field with 30 character limit, allow users to set from the geographical areas they are setting out to engage with. If user set it to global, it neither informs the followers or community where they are, nor does enlighten them as to whom they like to connect with.

\section{Think before you link}

Similar in any other online campaign, before sharing out users need to look in details of the value that they are adding to the followers (community) with the brand that they posted. Even merely by adding the URL of the website. This can be a creative approach to take the followers to the interesting places when on your outreach. But, a point to take note, never leave a guest on your doorstep. Make them feel welcome. Invite them in to find out more about the services, products or information.

\section{Your bio: your mission statement}

Your bio is your mission statement. It illustrates a great deal of thought as to what users share about themselves in the 160 characters. In addition your bio will be crawled by Google, as well as specialist Twitter search engines such as Twellow. But, it is a great deal of the social media credibility hinges upon what they say here, as well as what they don't say.

\section{Look over your shoulder; hold out your hand}

A lot of Twitter users fails to take note and be aware of who is following you. For some reason, there is a need to keep the doorstep clean and do not allow spam followers to be associated with the account. Users are encouraged to review and block inappropriate accounts regularly.

\section{Is your tweet stream an echo chamber?}

One of the mistakes that most librarians done in Twitter sphere is issuing corporate declarations and broadcast news. If this is the case, RSS feed will be a good approach.

An increase in the number of @ replies your Twitter account receives is both explicitly equivalent and directly proportional to customer engagement. A users feeds should have lots of interaction and engagement, plenty of evidence of the interest in and interaction with emerging communities. Then, they are doing a better job of managing a key element of the corporate social media portfolio.

It will be great to talk to people who have found their own way to them and are interested enough in what they do to ask them about it. It is better still to discover that they are talking to other members of their community independently about what the librarians do.

One of the language or symbol that a twitter users need to know is Hash Tag (\#). Basically hash tags can lead to be a community-driven convention for adding additional context and metadata to the tweets. In layman, it only added inline to the post. Users create a hash tag simply by prefixing a word with a hash symbol: \#hashtag. In addition, the use of hash tags is can be an emergent phenomena, and as such, etiquette is negotiable, as observation on users shares some have already expressed their distaste for hash tags. 
Hence, via the usage in sparingly and respectfully, hash tags can provide useful context and cues for recall, as well as increased utility for the track feature. On the other hand, it can be used excessively can cause annoyance, confusion or frustration, and may lead others to stop following. It is best to use hash tags explicitly when they are going to add value, rather than on every word in an update. In this case, this will lead to create a knowledge sharing database and the initial opportunity for short sentences (sharing of proverbs or peribahasa) is able to leverage from the situation.

A good rule of thumb to follow is to focus on the update share first, and only if it quantitatively adds value, to append one-three hash tags. There are no hard and fast rules, but Twitter should continue to be about answering the simple question or sentence structure. For example: "What are you doing" rather than "What tags apply to what you're doing?"

Hence, from the short study on the anatomy of twitter, the initial idea is a possible situation to leverage on to the technology. This wills also compliance with the learning in knowledge sharing and awareness for the Peribahasa. In addition, users will be aware of the language and use it (retweet it).

\section{DIGITAL HUMANITIES - PROVERBS (PERIBAHASA)}

One of the areas that allow us to studies is digital humanities. It is an area of research, teaching, and creation concerned with the intersection of computing and the disciplines of the humanities. Proverbs is usually studies in literature and language related subject. For this case, the idea is to look into Peribahasa, where the topic resides in the Malay literature and language. One of the interesting topic concern digital humanities, it relates in the creation of software, providing "environments and tools for producing, curating, and interacting with knowledge that is 'born digital' and lives in various digital contexts (Presner, 2010). And, studying the sentences structure in proverbs, they are usually a simple and concrete saying. It is popularly known and repeated, which expresses a truth, based on common sense or the practical experience of humanity.

Proverbs usually do not have long sentence structure. This actually fits the requirement of 140 characteristics. In this case, peribahasa will be a suitable initiative as a case study. This is because, peribahasa consists of a series of short phrases that has deep meanings and contains the richness of the language.

In an example given that Twitter is becoming increasingly important for academic communities, new, dedicated methodologies for the analysis and understanding of Tweet-based corpora are necessary, one study conducted by Ross, Terras, Warwick, \& Welsh (2011) shares how micro blogging technologies such as Twitter are used by and can benefit scholars. Thus, this is an indicated that recently, academics are leveraging Twitter to further their studies in the usage of language and impact of communication culture.

\section{CREATING THE KNOWLEDGE AWARESNESS VIA TWITTER (PERIBAHASA KITA: GUNAKANLAH!)}

Once, the basic understanding on functional usage of twitter, the community can now leverage on the technology to create the awareness in the usage of the proverbs. The next few diagrams illustrate the possibilities in leveraging the technology for outreach. 


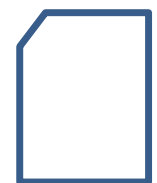

A website containing peribahasa can be share via twitter link, into the twitter's conversation sphere.

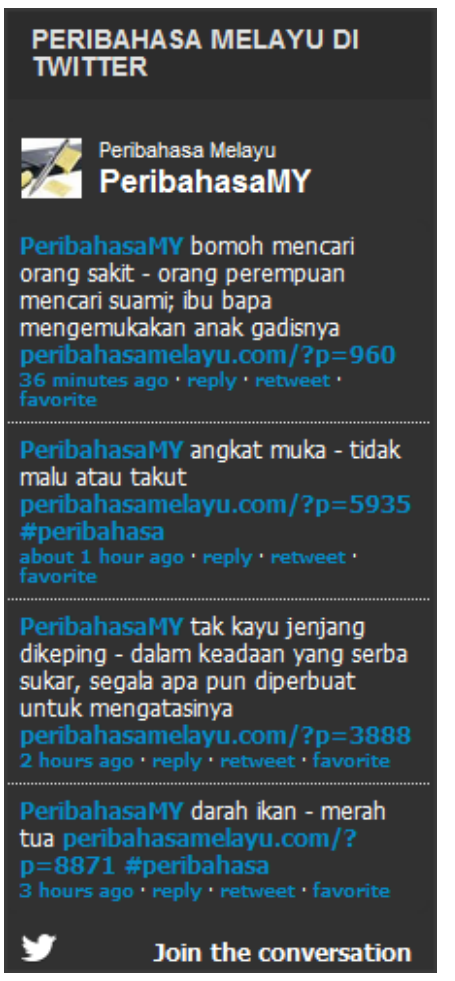

fils HazmanLabs $v$

\section{Share a link with your followers}

Laksana menggantang asap, mengukir langit |

http://peribahasamelayu.com/laksana-menggantang-asap-mengukir-langit/ via @bulanbahasa \#peribahasa \#bahasamelayu

Peribahasa Melayu @PeribahasaMY
Koleksi Peribahasa Melayu dan Maksud
http://peribahasamelayu.com/

\section{Twitter Basic Note}

\#peribahasa: The hash tag (\#), is used on Twitter for users to categorize their tweets.

By using hash tags that place in the tweet into an appropriate category, it would be easier to find by users who know how to search for hash tags.

@bulanbahasa: The @ means a Twitter update (a tweet) that is directed to another user in reply to their update.

Only 140 basic characters and be creative. 


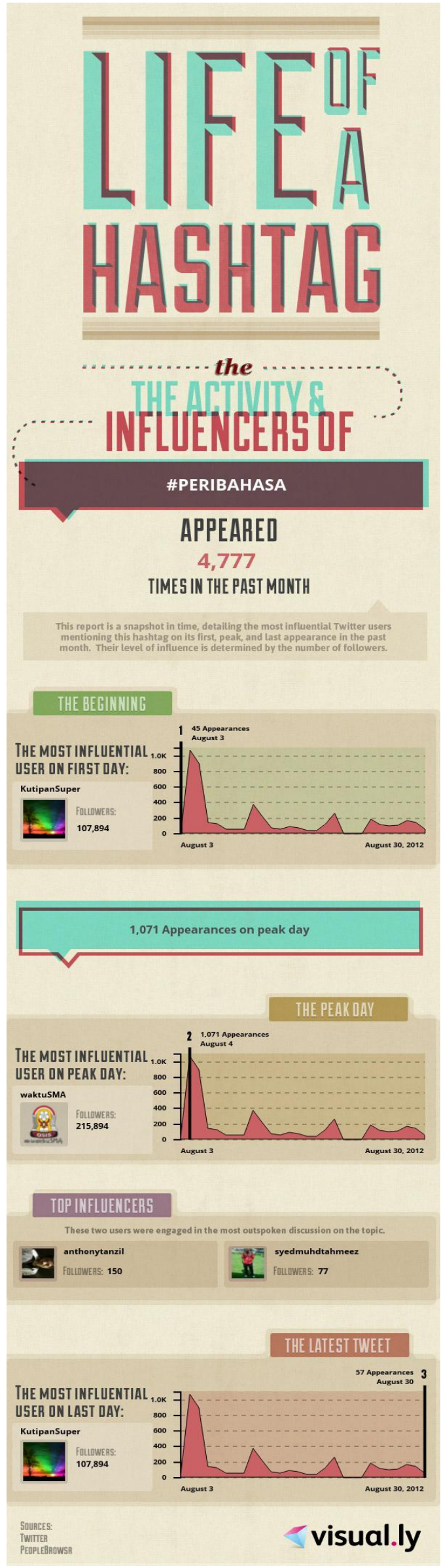

Data visualization is one of the interesting project that can be produced. Via this community tools by Visual.ly (http://visual.ly), users is able to generate a cool free infographic tool called "Life of a Hashtag". For this case, it is \#peribahasa, where the hashtag has been appeared in 4,777 times in the past month.

This report is a snapshot in time, detailing the most influential Twitter users mentioning this hashtag on its first, peak and last appearance in the past month. Their level of influence is determined by the number of followers.

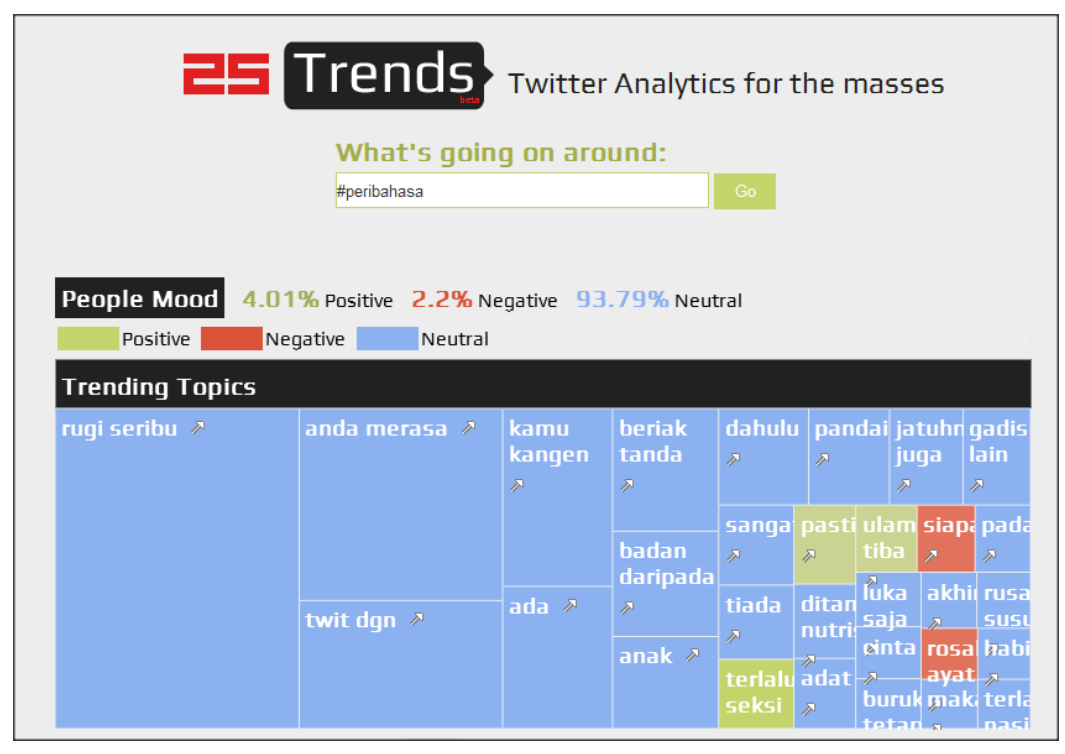

And, via the services like 25Trends (http://25trends.me/), the community could know what are they saying around a place, a topic at this moment. This site will search twitter for them

\begin{tabular}{|c|c|}
\hline Top Links & Top Tweets \\
\hline 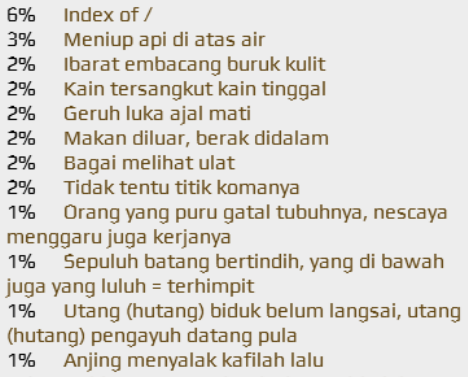 & 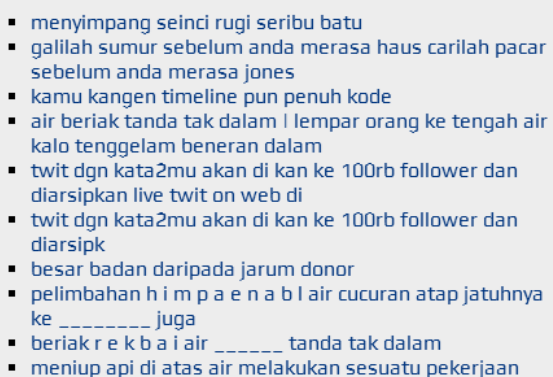 \\
\hline
\end{tabular}

around the hastag (\#peribahasa), analyses and aggregates the words, links and tags and provides them with a visual presentation of the buzzing words and a lot of other useful statistics 


\section{RESPONSED TO THE IDEA - BULAN BAHASA USING TWITTER}

Responding to the idea, this initiative is put in place in a recent national campaign organised by the Majlis Bahasa Melayu Singapura on a trail. The project is to collaborate and harness on the current notable twitters icon such as Imran Ajmain (song writer) and Riz Sunawan (news \& current affairs producer). Imran has followers more than $70 \mathrm{~K}$, following closely to this daily tweets, while Riz has about $10 \mathrm{~K}$. The idea is outreach, when each peribahasa (or simple proverbs or sayings) was tweeted out by the committee or community with these hashtags, \#bulanbahasa or \#peribahasa. And, these will be throughout the campaign week and tweeter domain.

While at Imran's side, data can be search and retrieve via the hashtag and to form lyrics for a composition of song. A true selection has to be filter and made here. But, the main objective is to create awareness of the language and encourage the community to use the Malay language in their daily life. Overall, the whole idea was to leverage on the technology and to bring in fun and creativity rather than just the traditional approach or outreach of the language.

\section{CONCULSION}

In conclusion, the initiative is able to leverage of twitter technology and there is a rise of digital humanities adopting the similar approach. This project is still an on-going process and the model is being relooked and redefines. This is also can be one of the potential ways for librarians to venture into digital humanities for the community and to communicate their resources to the community. One of the positive technology of twitter, it is viral and harness data for the community to venture into new digital space and research that leads to open sciences. After all, a living language is one which is being used whether in the Real World or the Digital World and this platform provides the opportunity for users of the language to read, learn, understand, engage and interact.

\section{REFERENCES}

Choy, M., Cheong, M. L. F., Laik, M. N., \& Shung, K. P. (2011). A sentiment analysis of Singapore Presidential Election 2011 using Twitter data with census correction. Applications; Computation and Language. Retrieved from http://arxiv.org/abs/1108.5520

Donath, j, \& Boyd, D. M. (2004). Public displays of connection. BT Technology Journal,, 22(3), 71-82. Retrieved from http://www.springerlink.com/content/uk574366j03j3652/?MUD=MP

Dugan, L. (2012). Twitter To Surpass 500 Million Registered Users On Wednesday - AllTwitter. Retrieved August 16, 2012, from http://www.mediabistro.com/alltwitter/500-millionregistered-users_b18842

Dunn, A. (2011). THE ARAB SPRING: REVOLUTION AND SHIFTING GEOPOLITICS: Unplugging a Nation: State Media Strategy During Egypt's. The Fletcher Forum of World Affairs. Retrieved from https://litigationessentials.lexisnexis.com/webcd/app?action=DocumentDisplay\&crawlid=1\&doctype $=$ cite $\&$ do $\mathrm{cid}=35+$ Fletcher + F. + World + Aff. $+15 \&$ srctype $=$ smi\&srcid $=3 \mathrm{~B} 15 \& \mathrm{key}=5 \mathrm{e} 5 \mathrm{ef} 12 \mathrm{dabf7f8a} 49 \mathrm{c} 04$ $50 \mathrm{f} 3 \mathrm{cb} 9 \mathrm{f} 32 \mathrm{eb}$

Dunn, J. (2012). 100 Ways To Use Twitter In Education, By Degree Of Difficulty |Edudemic. edudemic. Retrieved August 19, 2012, from http://edudemic.com/2012/04/100-ways-to-usetwitter-in-education-by-degree-of-difficulty/ 
Farhi, P. (2009). The Twitter Explosion No Title. American Journalism Review. Retrieved from http://www.ajr.org/article.asp?id=4756

Foo, S., Judy, N., \& A, S. (2008). Going Virtual for Enhanced Library Experience : a Case Study of the National Library of Singapore Library, a Time for Re-Think. VALA 2008. Melbourne Australia.

Grossman, L. (2009). Iran Protests: Twitter, the Medium of the Movement. Time World. Retrieved from http://www.time.com/time/world/article/0,8599,1905125,00.html

Honan, M. (2007). Apple unveils iPhone. Macworld. Retrieved from http://www.macworld.com/article/1054769/iphone.html

Ingram, M. (2010). Twitter Annotations Are Coming — What Do They Mean For Twitter and the Web? Retrieved from http://gigaom.com/2010/06/20/twitter-annotations-are-coming-whatdo-they-mean-for-twitter-and-the-web/

Java, A., Xiaodan, S., Finin, T., \& Tseng, B. (2007). Why We Twitter: Understanding Microblogging Usage and Communitiesle. Procedings of the Joint 9th WEBKDD and 1st SNAKDD Workshop 2007. Retrieved from http://ebiquity.umbc.edu/paper/html/id/367/

Johnson, P. R., \& Yang, S. (2009). Uses and gratifications of Twitter: An examination of user motives and satisfaction of Twitter useo Title. Association for Education in Journalism and Mass Communication. Retrieved from http://citation.allacademic.com//meta/p_mla_apa_research_citation/3/7/6/3/6/pages376367/p37 6367-1.php

Kirkpatrick, M. (2010). What Twitter Annotations Mean. Retrieved August 21, 2012, from http://www.readwriteweb.com/archives/what_twitter_annotations_mean.php

Krikorian, R. (2010). Map of a Twitter status object - mehack. Retrieved August 21, 2012, from http://mehack.com/map-of-a-twitter-status-object

Musfirah, H. (2012, May 25). Court hearing into SMRT's train disruptions concludes. Channelnewsasia. Retrieved from http://www.channelnewsasia.com/stories/singaporelocalnews/view/1203481/1/.html

Oiong, O. (2012, May 24). SMRT foresees fewer breakdowns by year-end. Channelnewsasia. Retrieved from http://www.channelnewsasia.com/stories/singaporelocalnews/view/1203322/1/.html

Ortmann, S. (2011). Singapore: Authoritarian but Newly Competitive. Journal of Democracy, 22(4), 153-164. Retrieved from http://muse.jhu.edu/journals/journal_of_democracy/v022/22.4.ortmann.html

Perez, S. (2010). This is What a Tweet Looks Like. Retrieved August 21, 2012, from http://www.readwriteweb.com/archives/this_is_what_a_tweet_looks_like.php

Presner, T. (2010). Digital Humanities 2.0: A Report on Knowledge. Retrieved from http://cnx.org/content/m34246/latest/ 
Rheingold, H. (2000). The virtual community: Homesteading on the electronic frontier. Cambridge: The MIT Press. Retrieved from http://www.rheingold.com/vc/book/

Ross, C., Terras, M., Warwick, C., \& Welsh, a. (2011). Enabled backchannel: conference Twitter use by digital humanists. Journal of Documentation, 67(2), 214-237. doi:10.1108/00220411111109449

Saletan, W. (2011). Is the Internet driving the revolutions of the Arab Spring? Slate. Retrieved from http://www.slate.com/articles/technology/future_tense/2011/07/springtime_for_twitter.html

Sarno, D. (2009). On Twitter, mindcasting is the new lifecasting. Los Angeles Times. Retrieved from http://latimesblogs.latimes.com/technology/2009/03/on-twitter-mind.html.

Siegler, M. (2010). An Early Look At Twitter Annotations Or, "Twannotations"| TechCrunch. Retrieved August 21, 2012, from http://techcrunch.com/2010/05/08/twitter-annotations/

Thompson, C. (2008). Brave new world of digital intimacy. The New York Times. Retrieved from http://www.nytimes.com/2008/09/07/magazine/07awareness-t.html?_r=1\&pagewanted=all.

Tumasjan, A., Sprenger, T. O., Sandner, P. G., \& Welpe, I. M. (2010). Predicting Elections with Twitter: What 140 Characters Reveal about Political Sentiment. Proceedings of the Fourth International AAAI Conference on Weblogs and Social Media. Retrieved from http://www.aaai.org/ocs/index.php/ICWSM/ICWSM10/paper/viewFile/1441/1852

Yung Hui, L. (2010). Twitter in Asia: Total Users, by Country. Grey Review. Retrieved August 18, 2012, from http://www.greyreview.com/2010/01/26/twitter-in-asia-total-users-by-country/ 